Article

\title{
Using a Hybrid Cost-FMEA Analysis for Wind Turbine Reliability Analysis
}

\author{
Nacef Tazi ${ }^{1, *}$, Eric Châtelet ${ }^{1}$ and Youcef Bouzidi ${ }^{2}$ \\ 1 Institut Charles Delaunay, LM2S/STMR, CNRS, University of Technology of Troyes, 12 rue Marie Curie, \\ CS 42060, 10004 Troyes CEDEX, France; eric.chatelet@utt.fr \\ 2 Institut Charles Delaunay, CREIDD, CNRS, University of Technology of Troyes, 12 rue Marie Curie, \\ CS 42060, 10004 Troyes CEDEX, France; youcef.bouzidi@utt.fr \\ * Correspondence: nacef.tazi@utt.fr or naceftazi@gmail.com; Tel.: +33-325-717-600
}

Academic Editor: Frede Blaabjerg

Received: 20 December 2016; Accepted: 17 February 2017; Published: 27 February 2017

\begin{abstract}
Failure mode and effects analysis (FMEA) has been proven to be an effective methodology to improve system design reliability. However, the standard approach reveals some weaknesses when applied to wind turbine systems. The conventional criticality assessment method has been criticized as having many limitations such as the weighting of severity and detection factors. In this paper, we aim to overcome these drawbacks and develop a hybrid cost-FMEA by integrating cost factors to assess the criticality, these costs vary from replacement costs to expected failure costs. Then, a quantitative comparative study is carried out to point out average failure rate, main cause of failure, expected failure costs and failure detection techniques. A special reliability analysis of gearbox and rotor-blades are presented.
\end{abstract}

Keywords: failure mode and effects analysis (FMEA); wind turbine; criticality; expected failure cost; reliability analysis

\section{Introduction}

According to the Global Wind Energy Council, wind energy has been in a rapid growth mode since 2000, and the world now counts more than 310,000 spinning wind turbines. Wind turbine technology is constantly improving [1,2]. This rapid growth also affects the reliability and performance of wind turbines [3], since new technologies rely on more reliable components. Reliability of a component is "the probability that it will perform its required function under stated conditions for a specified period of time" [4-6]. Reliability analysis deals with causes of failure, their probabilities or frequencies of failure and how to prevent them to occur in systems. Several studies have been conducted to analyze the reliability of the main components of the wind turbine [7-9]. The different methods used for reliability analysis can be classified into three main kinds: qualitative, quantitative or hybrid [10]. While qualitative approaches are based on analytical estimation and are easy to apply, quantitative techniques cost more in resources and skill sets, but provide detailed understanding of the system [11]. A compromise between both methods provides best results. That is why hybrid methods that use both qualitative and quantitative methods or modify a method by adding new indicators have become more popular. The most used methodologies in industry in different phases of the product/process (1-Concept; 2-Process; 3-Design; 4-Commissioning; 5-Operation; 6-Modification; 7-Decommissioning) are briefly presented in Table $1[10,12,13]$. Methodologies are compared according on which phases of project are used, whether they are qualitative, quantitative and if they can be hybrid, if the results obtained can be reproduced (subjective/objective), the amount of data needed to perform the analysis and how precise the results of the analysis are (accuracy). 
As seen in the Table 1, failure mode and effects analysis (FMEA), Fault tree analysis (FTA) and cause consequence analysis (CCA) methodologies are more suited for more detailed and objective analysis of wind turbine systems. However, the CCA technique is less accurate than FMEA and FTA [14]. Moreover, FTA is based on a deductive logic that supposes failures and their probability of occurrence are already known. That is why FMEA methodology is more suitable to study the failure behavior of system components. In addition to this, the assessment of FMEA indicators (severity, occurrence and detection) are often based on standard scales or empirical ranking (minor, marginal and catastrophic). Some hybrid FMEAs such as cost-FMEA used in the automotive industries have used these ranking techniques and present other methodologies to calculate the criticality of components without using the standard indicators $[15,16]$.

Table 1. Brief description of risk assessment methods and their suitability to the different product/process phases. FMEA: failure mode and effects analysis.

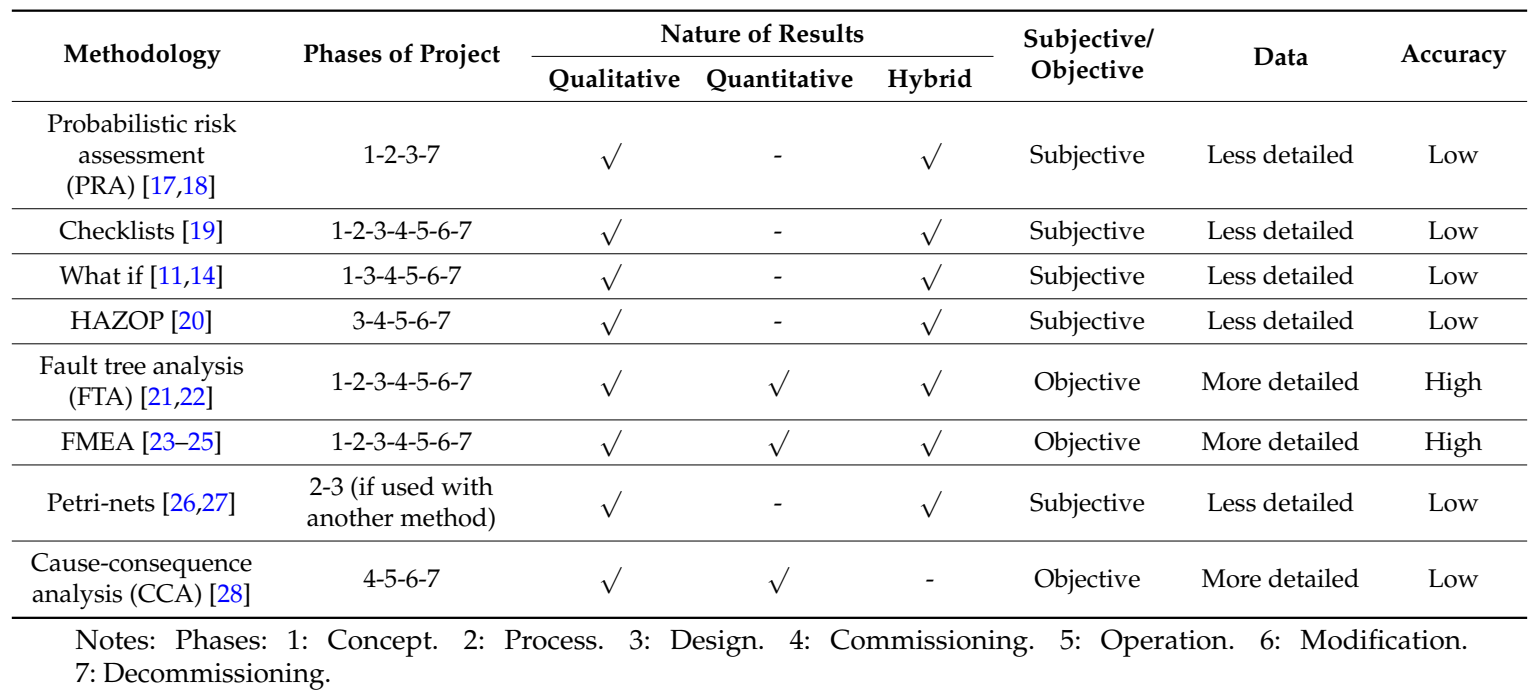

The aim of this study is to apply hybrid cost-FMEA to wind turbines. It has as objectives the identification of:

- Average annual failure rates of wind turbines sub-systems;

- Main cause of failure;

- Expected failure costs;

- Critical components of wind turbine system (criticality). Criticality is calculated as the total expected failure costs times the relative failure rate.

The remainder of the study will compare the results obtained with similar FMEA analyses of wind turbine components. Besides, a special reliability overview of wind turbine gearbox and rotor-blades will be presented, since the results showed they are the most critical components in wind turbine systems.

The hybrid cost-FMEA presented in this paper is reliability analysis oriented, and safety analysis will not be part of this study. Indeed, the objective of this study is the reliability analysis of wind turbine components at entry level/design phases. At this step, no risk or safety analysis have been taken into account.

This paper is divided as follows: Section 2 describes the generic wind turbine sub-system components used in this study. Section 3 describes the hybrid cost-FMEA methodology. Section 4 presents the results and the objectives of this study, including a comparative study. Finally, Section 5 presents our conclusions and directions for future research. 


\section{The Failure Mode and Effects Analysis (FMEA) Methodology}

\subsection{Introduction}

Failure mode and effect analysis (FMEA) is a powerful reliability engineering methodology that provides a means of comparing and assessing the system configuration [29]. This methodology evaluates systems component by component and identifies their failure modes and their effects on system function and other system components. FMEA has been used in different industries, including nuclear [30], semiconductor and automotive industries [31]. This last industry requires the use of this methodology to support the design and manufacturing/assembly of its products (QS 9000) [32]. Different types of FMEA are used for different systems. This approach is also certified (CEI 60812:2006) [33]. Its major aim is to detect all the possible potential problems in a complex system and their occurrence probabilities.

\subsection{State of the Art}

Compared to other reliability methods such as FTA, FMEA is an inductive method and is more suited for systems that contain little or no redundancy [22,23]. It is also recommended for exhaustively identifying local and global failure effects [34,35].

We developed here some major references about FMEA methodologies applied for the wind turbines system. In this literature, Sheng and Veers [36] conducted a FMEA analysis focused on wind turbine drivetrain sub-systems, where criticality was weighted by the downtime caused by each component. Shafiee and Dinmohammadi [23] and Kahrobaee and Asgarpoor [24] investigated the cost-priority-number of wind turbine components based on non-detection possibility, cost consequence of failures and probability of failures. Arabian-Hoseynabadi et al. [37], Tavner et al. [38], Bharatbhai [39] and Sinha and Steel [40] weighted component criticality with basic rating scales for severity, occurrence and non-detection. Dinmohammadi and Shafiee in [41] developed a fuzzy indicator to assess component criticality. Das et al. in [42] and Zhou et al. [43] presented FMEA analyses based on expert assessment indicators. Fischer et al. and Andrawus et al. in $[44,45]$ used this methodology to present an optimized maintenance policy for wind turbines. These last studies used large scales or empirical ranking for the identification of some indicators, mainly the rating for severity and detection of failure. Besides, according to the literature, only authors in $[23,24]$ used cost-based indicators to assess the criticality of components. In these last studies, a cost priority number (CPN) (based on occurrence, cost and detectability) was developed for criticality assessment of wind turbine components, non-detectability indicator was based on failure vulnerabilities ranking, which is difficult to assess in real industrial cases [23]. Other significant references and how criticality was assessed are presented in Table 2.

\subsection{Discussion: Criticality Assessment}

The authors mentioned in the state of art above used different methodologies to assess the criticality of components, and the table below summarizes how authors in the literature define the criticality of wind turbine components.

As stated in Table 2, authors used to rely on standard ranking scales of severity, occurrence and detection. This method was then developed to make it more practical for wind turbine systems, and fuzzy or expert approaches were introduced at this step to parametrize the proposed scales. This methodology was efficient, but has several limitations and weaknesses, particularly for the risk priority number (RPN) value that was not informative enough to assess component criticality. To overcome these limitations, Shafiee and Dinmohammadi [23] and Kahrobaee and Asgarpoor [24] developed a CPN based on probability, incurred failure costs and fault detection possibility. This last method proved to be more suitable for wind turbine reliability analysis and has overcome the limitations of the RPN limitations. However, it also need more data to evaluate probabilities or indicators to calculate the components $\mathrm{CPN}$. 
Table 2. Criticality assessment according to authors. RPN: risk priority number; $\mathrm{CPN}$ : cost priority number.

\begin{tabular}{|c|c|c|c|c|c|c|c|c|c|c|}
\hline Criticality & $\begin{array}{l}\text { Component } \\
\text { Downtime }\end{array}$ & $\begin{array}{l}\text { Failure } \\
\text { Rate }\end{array}$ & $\begin{array}{c}\text { Failure } \\
\text { Probability of } \\
\text { Occurrence }\end{array}$ & $\begin{array}{c}\text { Cost } \\
\text { Consequence } \\
\text { of a Failure }\end{array}$ & $\begin{array}{c}\text { Fault } \\
\text { Detection } \\
\text { Possibility }\end{array}$ & $\begin{array}{l}\text { Severity } \\
\text { Rating } \\
\text { Scale }\end{array}$ & $\begin{array}{l}\text { Occurrence } \\
\text { Rating } \\
\text { Scale }\end{array}$ & $\begin{array}{l}\text { Detection } \\
\text { Rating } \\
\text { Scale }\end{array}$ & RPN & CPN \\
\hline [36] & $\sqrt{ }$ & - & - & - & - & - & - & - & $\sqrt{ }$ & - \\
\hline [23] & - & - & $\sqrt{ }$ & $\sqrt{ }$ & $\sqrt{ }$ & - & - & - & - & $\begin{array}{l}\text { Based on failure costs } \\
\text { consequences and } \\
\text { probabilities of failure }\end{array}$ \\
\hline [24] & - & - & $\sqrt{ }$ & $\sqrt{ }$ & $\sqrt{ }$ & - & - & - & - & $\begin{array}{l}\text { Based on cost of failures } \\
\text { and number of failures }\end{array}$ \\
\hline$[37-40,46-50]$ & - & - & - & - & - & $\sqrt{ }$ & $\sqrt{ }$ & $\sqrt{ }$ & $\sqrt{ }$ & - \\
\hline$[41,51]$ & - & - & - & - & - & $\begin{array}{c}\text { Fuzzy } \\
\text { approach }\end{array}$ & $\begin{array}{c}\text { Fuzzy } \\
\text { approach }\end{array}$ & $\begin{array}{c}\text { Fuzzy } \\
\text { approach }\end{array}$ & $\sqrt{ }$ & - \\
\hline$[42,43]$ & - & - & - & - & - & $\begin{array}{l}\text { Expert } \\
\text { approach }\end{array}$ & $\begin{array}{l}\text { Expert } \\
\text { approach }\end{array}$ & $\begin{array}{l}\text { Expert } \\
\text { approach }\end{array}$ & $\sqrt{ }$ & - \\
\hline This study & $\sqrt{ }$ & $\sqrt{ }$ & - & $\sqrt{ }$ & - & - & - & - & - & $\begin{array}{c}\text { Based on component } \\
\text { failure rates, its average } \\
\text { downtimes and expected } \\
\text { costs of failure }\end{array}$ \\
\hline
\end{tabular}


Nowadays, the wind turbine industry is more mature. More public data about component failure rates, their downtime and repair costs are available and therefore CPNs used to evaluate the criticality of wind turbine component can be updated and optimized.

In order to overcome these limitations, this study presents a hybrid cost-FMEA [15,16]. This methodology combines failure rates (based on failure downtimes), expected failure costs and loss of production costs to identify the criticality of system components. The novelty of this method is that all the three indicators are based on available data in wind turbine industry and does not need probability or scaling assessment. The three indicators (failure rate, expected failure costs and loss of production costs) need less data than the compared references $[23,24]$ for criticality assessment. Besides, they are not based on ranking scales like other previous references [37-39].

The criticality of each sub-system is calculated as the total expected failure costs times the corresponding failure rate. Expected failure cost can be estimated using the following Equation (1):

$$
\text { Expected failure cost }=\sum_{n_{\text {components }}} p_{n} c_{n}+\text { loss of production cost }
$$

Loss of production cost $=$ expected production during downtime $\times$

$$
\text { Capacity factor } \times \text { Selling tariff }
$$

$$
\text { Component criticality }=\text { Expected failure cost } \times \text { Failure rate }
$$

where " $p_{n}$ " and " $c_{n}$ " are the probability and the cost associated to a particular failure occurring in component " $n$ ", respectively. The loss of production cost (Equation (2)) takes into account the energy supposed to be generated during the downtime of wind turbine components. To calculate the loss of production indicator, a standard electricity selling tariff in France $(0.082 € / \mathrm{kWh})$ and a capacity factor of $30 \%$ is used in this Equation (2). Loss of production costs can also represent the severity of each sub-system. The proposed criticality will be discussed in Section 4.3.

The aim of the FMEA presented in this work is to identify failure modes along with possible causes and effects for a generic wind turbine. The general hybrid cost-FMEA flowchart used for this study is presented in Figure 1.

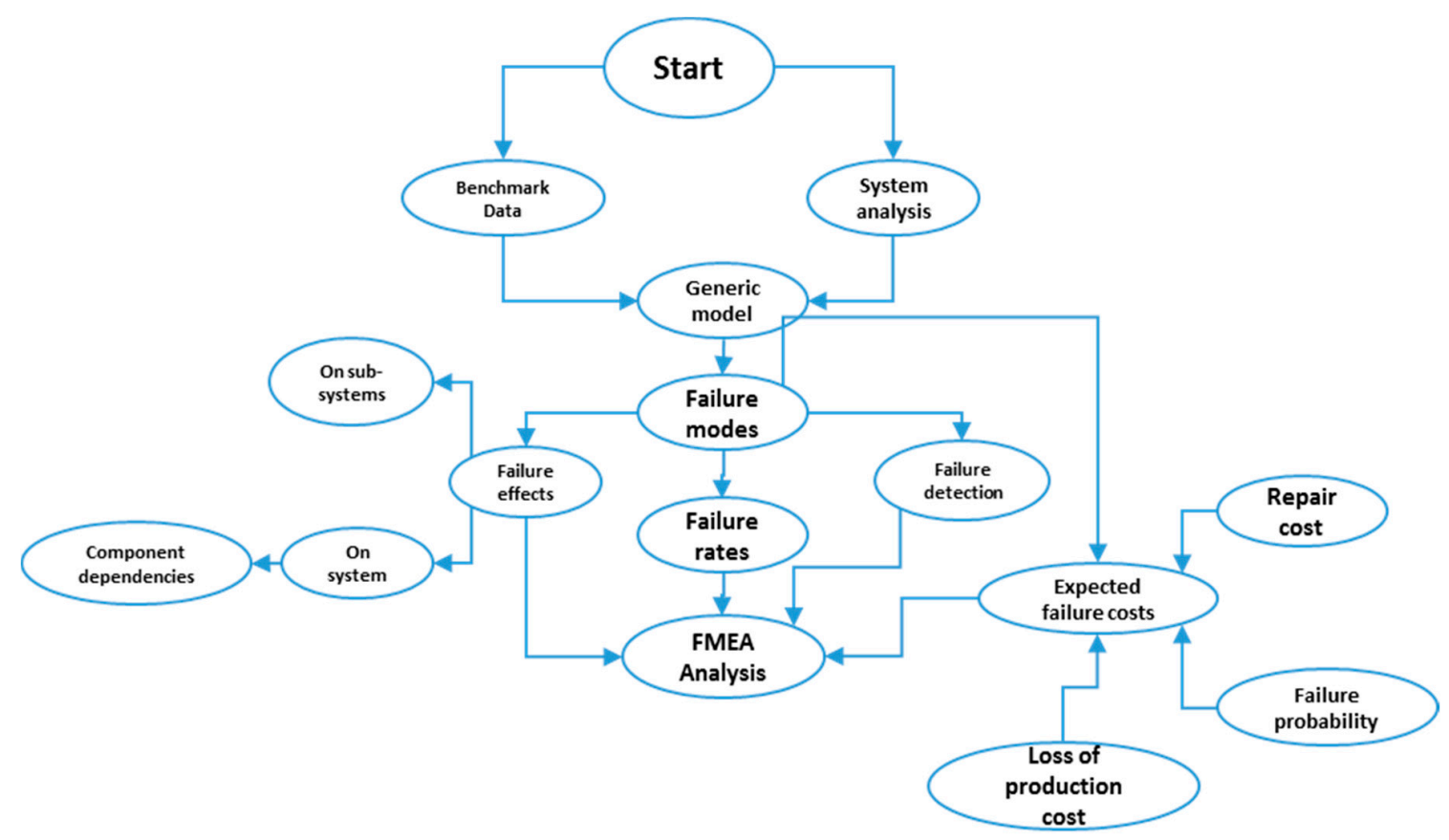

Figure 1. Flowchart representing the hybrid cost-FMEA process followed in this study. 
As seen in Figure 1, we firstly proceed with a system analysis. This step generates the global configuration of the wind turbine system, its sub-systems, components and sub-components (Section 3). Next failure modes are investigated for each sub-system. The identification of failure causes has been performed by looking at the system in a holistic way. For each failure mode how it can be detected on the one hand and the failure effects on sub-systems and the global system on the other hand are investigated. This will allow us to describe the dependencies in the wind turbine system (this part was not presented in this paper). In order to define critical components and sub-systems, an expected failure cost was developed. This indicator was extracted from the life cost-based FMEA $[15,16]$. Cost is a universal factor that can be easily understood in terms of criticality and severity among engineers and others.

In order to simplify calculus, no failure dependency is supposed between wind turbine system components. The holistic causes will allow us to determine the expected failure costs of each sub-systems. A benchmark was made in the literature and from real wind farms in Europe. Thus, failure rates are compiled from $[23,37]$ and from:

- Windstats data of 7000 wind turbines, from Denmark and Germany [52];

- LWK data of 650 wind turbines, from Germany;

- WMEP data of 1500 wind turbines, from Germany [53];

- Vindstat (VPC) data of 80 wind turbines, from Sweden [54];

- VTT data of 105 wind turbines, from Finland [55];

- Former Garrad Hassan energy consultancy data collected from $14 \mathrm{GW}$ wind farms [56].

Since failure rates extracted from these database are location-dependent, data may be influenced by humidity, temperature, wind distributions, etc. Failure rates will be adjusted with standard deviation. This measure will be used to quantify the variation of dispersion of a set of data [57]. It will thus identify how much data vary from the average value. Consequently, a high standard deviation shows that data is widely spread (so less reliable), whereas low standard deviation shows that data are clustered closely around the average value.

The benchmarking method for failure rates used data extracted from the 10th European database and investigated. Then, the average failure rate for each sub-system is calculated with a standard deviation for every sub-system average failure rate.

Based on this data, a general overview of the analysis is proposed in Table A1. As seen in this table, for each component of wind turbine sub-systems is given:

- Failure modes;

- Failure causes;

- Failure consequences;

- Annual average failure rate

- Failure effects on sub-system and on global system

- Failure detection techniques.

Expected failure costs and the criticality of each sub-system are presented in Section 4.

\section{Wind Turbine System Model}

Different wind turbines with different configurations exist in the market, and they are classified by different electrical, mechanical, control designs or power control ability [23,37]. To perform our analysis, we chose the most common type of wind turbines installed in onshore wind farms. These wind turbines vary from 2 to 3 megawatts (MW) [58]. Table 3 presents the main existing wind turbine systems available in European and French markets. As seen in the table, most wind turbine configurations are equipped with gearboxes, converters and other main sub-systems [2,59-61]. These common sub-systems will help us to define a generic configuration for the FMEA analysis. Figure 2 presents the 
main components of this configuration. Each main component (sub-system) contains a variety of other components. The generic wind turbine system is composed of 11 sub-systems (see Figure 2). Failure cause, failure rate, failure effects, failure detection and expected failure costs will be generated for each one of these sub-systems.

Table 3. Main existing wind turbine systems in European and French Market.

\begin{tabular}{|c|c|c|c|}
\hline Type of Generator & Turbine Concept & Gearbox/Gearless & Converter \\
\hline \multirow{2}{*}{$\begin{array}{l}\text { Single cage induction } \\
\text { generator (SCIG) }\end{array}$} & Fixed speed & Gearbox (multiple stage) & No \\
\hline & Variable speed & Gearbox (multiple stage) & Yes (full scale) \\
\hline \multirow{2}{*}{$\begin{array}{c}\text { Permanent magnet } \\
\text { synchronous generator (PMSG) }\end{array}$} & Variable speed & Gearless & Yes (full scale) \\
\hline & Variable speed & $\begin{array}{c}\text { Gearbox } \\
\text { (single or multiple stage) }\end{array}$ & Yes (full scale) \\
\hline $\begin{array}{l}\text { Doubly fed induction } \\
\text { generator (DFIG) }\end{array}$ & Variable speed & Gearbox (multiple stage) & Yes (partial scale) \\
\hline $\begin{array}{l}\text { Electrically exited synchronous } \\
\text { generator (EESG) }\end{array}$ & Variable speed & Gearless & Yes (partial \& full scale) \\
\hline $\begin{array}{l}\text { Wound rotor induction } \\
\text { generator (WRIG) }\end{array}$ & $\begin{array}{l}\text { Limited variable } \\
\text { speed }\end{array}$ & Gearbox (multiple stage) & Yes (partial scale) \\
\hline $\begin{array}{l}\text { Brushless Doubly Fed Induction } \\
\text { Generator (BDFIG) }\end{array}$ & variable speed & Gearbox (multiple stage) & Yes (partial scale) \\
\hline
\end{tabular}

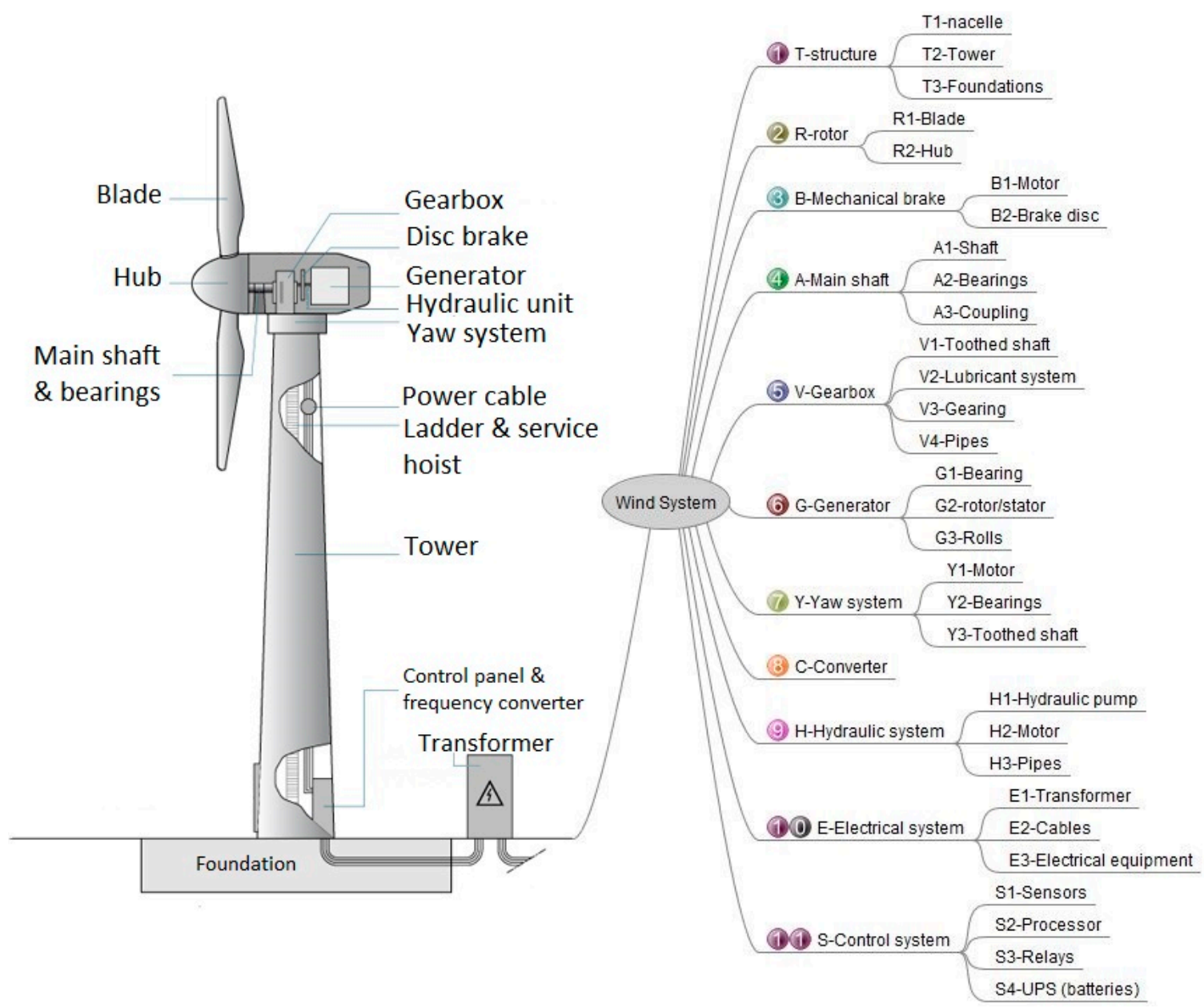

Figure 2. Main components of a 2-3 MW wind turbine. 


\section{Failure Mode and Effects Analysis (FMEA) Results}

\subsection{Failure Distribution in Wind Turbine Sub-Systems}

According to different data from the literature [23,37] and from wind farms [52-55,62], average failure rates of generic 2-3 MW wind turbine sub-systems are presented in Figure 3, where we can see that only $20 \%$ of the sub-systems (control, electric and converter sub-systems) cause more than $50 \%$ of the total failures of the wind turbine system. Indeed, control, electrical and converter sub-systems fail frequently during operation. Besides, the standard deviation for wind turbine components is low, which means that data are clustered closely around the average value token for this analysis (ratios of standard deviation values and average value are up to $5 \%$ for the first eleven sub-systems, and $9 \%$ for the others (see Figure 3), this ratio is $2 \%$ for gearbox and $4 \%$ for rotor-blades).

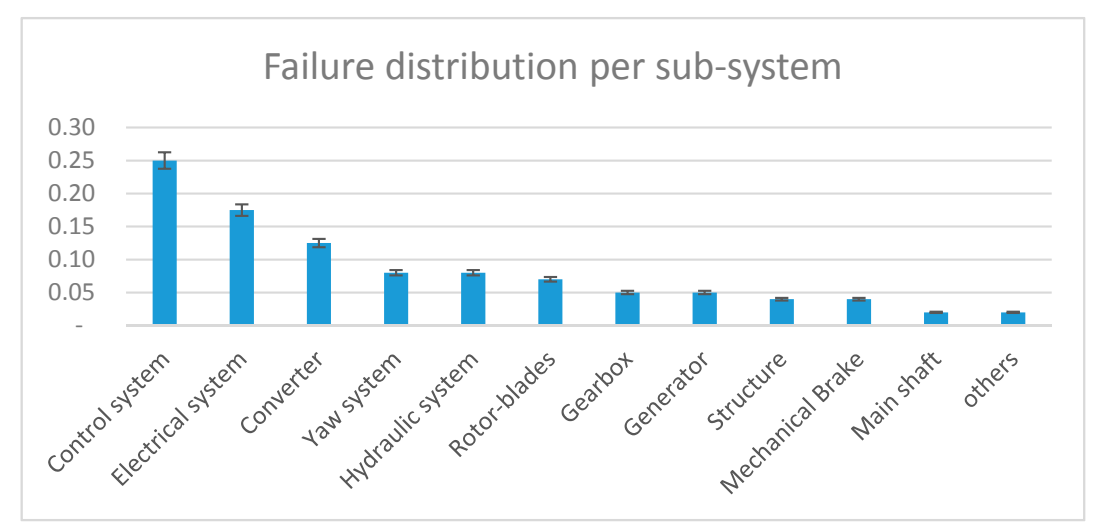

Figure 3. Failure distribution per sub-system.

\subsection{What Other Large Surveys in Europe Say}

LWK and WMEP [53] are one of the largest wind turbine surveys that studied more than 21,000 turbine years and their downtime over 13 years. Figure 4 presents an overview of this study. We notice in this figure that electrical and control systems cumulate the most failures in a wind turbine, which is in line with the Figure 3. However, sub-systems such as gearbox causes an important downtimes if failures occur. This is also explained by the complexity of maintenance of this sub-system [36].

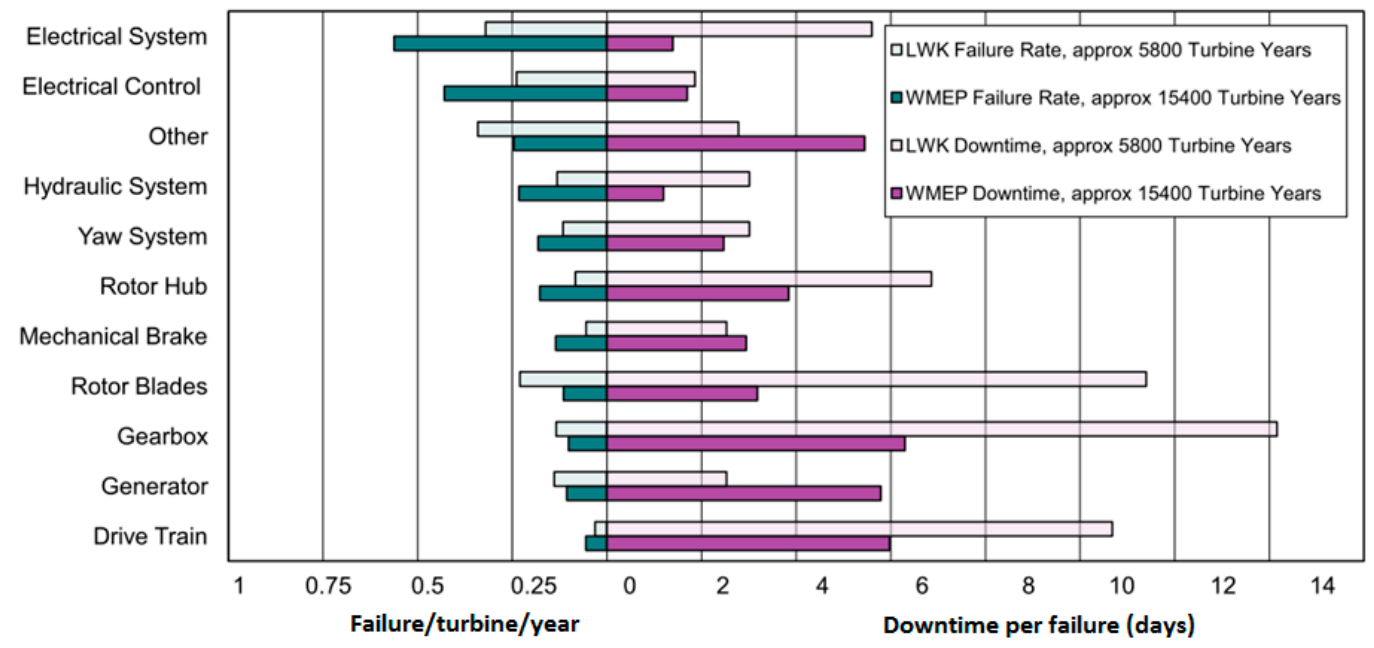

Figure 4. Failure per turbine per year and downtime from two large surveys of European onshore wind turbines over 13 years (LWK and WMEP). 


\subsection{The Main Cause of Failure}

Wear is the main and most frequent cause of failure revealed by this analysis. Wear is defined as the progressive loss of substance resulting from mechanical interaction between two contacting surfaces [63]. In comparison with other studies, authors in [37,64] revealed that corrosion (wear) is in the top root causes in wind turbine components. Ribrant [63] stated that wear causes the majority of failures in wind turbine mechanical components. Sheng in [65] presented the main results of the upwind project in the UK wind farms, where wear is the main cause of failure. Figure 5 shows the most frequent failures in the wind turbine system revealed from this last study.

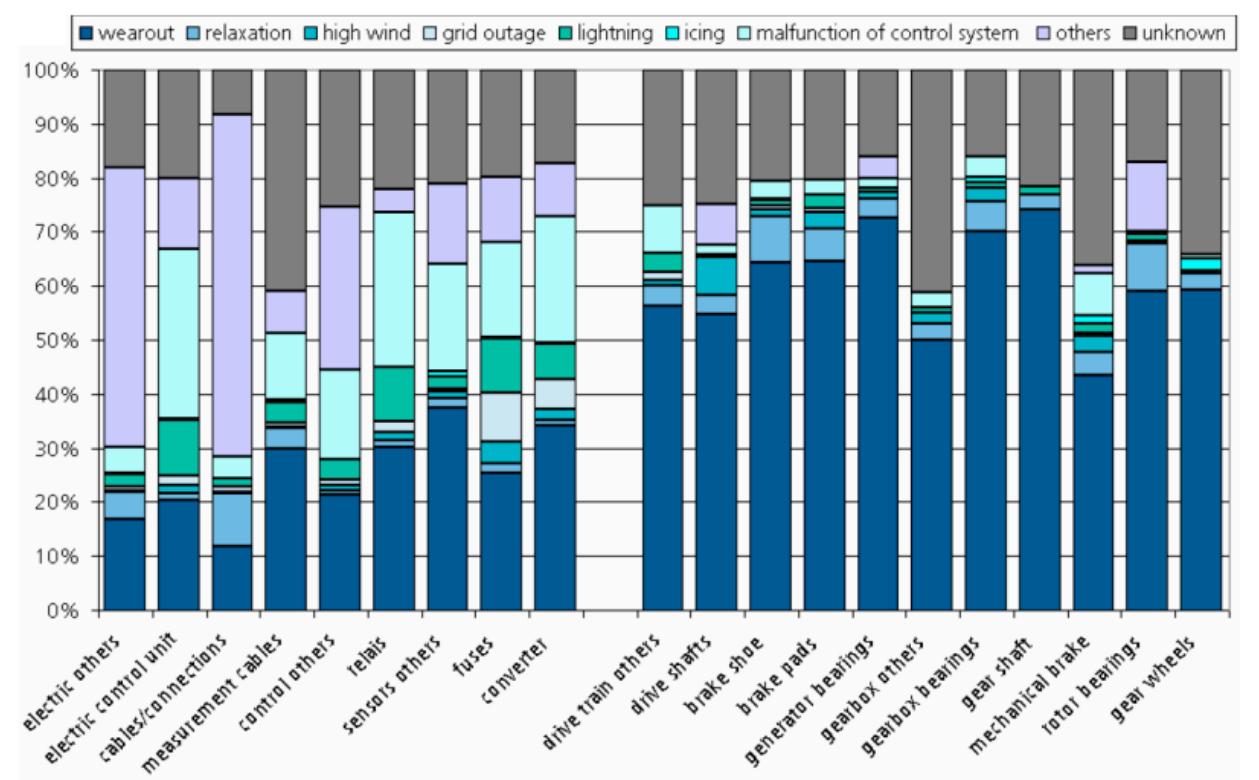

Figure 5. Share of failures in the wind turbine system [65].

Different wear types can be present in wind turbine components. According to [63], wear can be present in components as an abrasive, corrosive or erosive wear. Abrasive and corrosive wears seem to be the most frequent wear types in components. This cause of failure (wear) leads to damage in drivetrain systems whereas the failure rate of composite sub-systems such as blades are more influenced by material fatigue (crack evolution).

\subsection{Expected Failure Cost}

Cost is a universal term that can be easily understood in terms of criticality and severity among engineers and others. Expected failure cost can be estimated using Equation (1). To assess the sub-systems failure costs, an exponential failure rate (Number/year); that lead to component replacement; is used [21,63]. Average replacement costs of wind turbine sub-systems (2-3 MW) were taken from different references [66-68]. The replacement cost takes into account the cost of the components, crane cost and labor cost. Loss of production cost takes into account a standard selling tariff and capacity factor in France (see Section 3). Table A2 presents the failure rates (Number/year), reliability data, replacement cost of each sub system, final expected failure cost and average loss of production cost. Figure 6 presents the expected costs of failure for wind turbine sub-systems (extracted from Table A2). Structure failure supposes a complete failure of the structure (Tower/foundations/nacelle), this component rarely fail in a holistic way (annual average failure rate: 0.09). Thus, it will not be taken into account for reliability and criticality analysis. Thus, the components that generate high expenses are Gearbox and Rotor-blade sub-system. Shafiee \& Dinmohammadi and Kahrobaee \& Asgarpoor in $[23,24]$ using CPN indicators also confirmed that these two sub-systems (gearbox and rotor-blade) are on the top most critical sub-systems in wind turbines. 


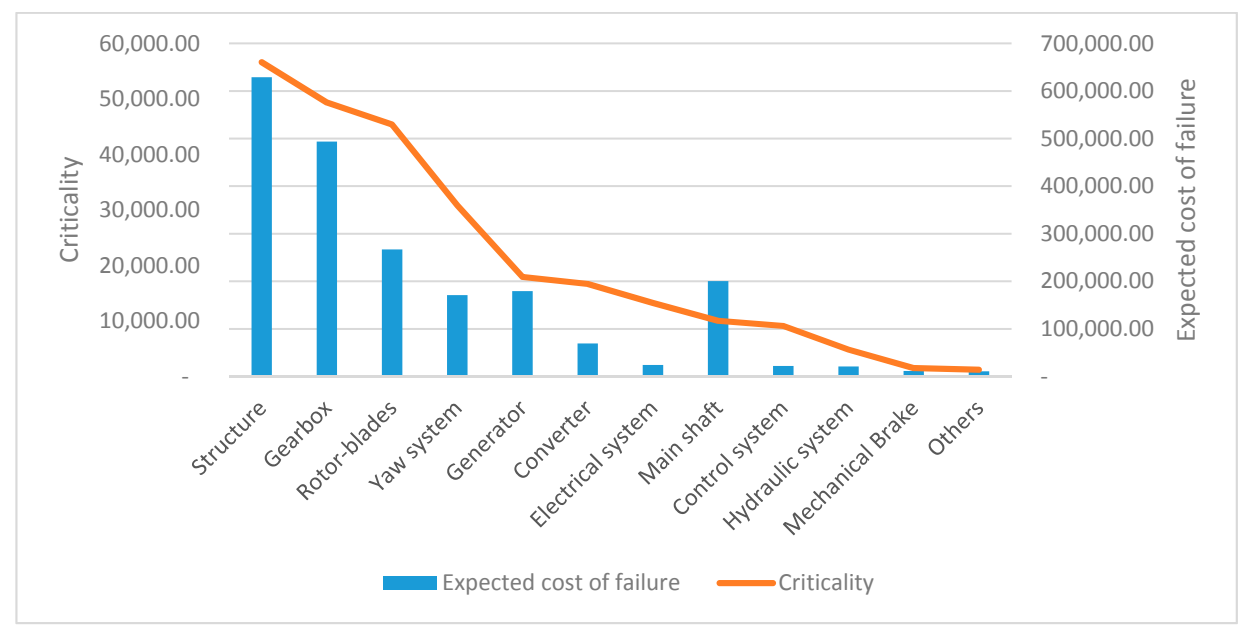

Figure 6. Expected costs of failure and criticality for wind turbine sub-systems.

\subsection{Criticality of Sub-Systems}

Criticality is calculated as the expected failure cost of each sub-system times its failure rate. Results are presented in Table A2 and Figure 6 presents the criticality for wind turbine sub-systems (extracted from Table A2). According to the Figure 6 (based on Table A2), and without taking into account the structure's failure, we can notice that the most critical components are the gearbox and rotor-blade sub-systems. Figure 4 also shows that these sub-systems generate high downtimes. Besides, according to Table A2, replacement and loss of production costs generated by the gearbox and rotor-blade sub-systems are the highest. These critical components, inter alia, exist in almost all industrial wind turbine systems (excluding gearless wind turbines) [69]. The next two sections present an overview of gearbox and rotor-blade reliability analysis.

Results of this study show similar main results as other cost-FMEA analyses [23,24], the novelty of this analysis being the need of less data for reliability and criticality analysis than previous studies. In this paper, cost factor was based on expected failure cost, occurrence factor was based on average failure rate extracted from wind turbine databases and weighted with standard deviation and severity factor was based on loss of production caused by failure modes. Standard criticality or risk/cost-priority-number based on ranking scales or probabilities have been overcome.

\subsection{Gearbox-A Reliability Overview}

Data from the literature shows that gearboxes usually don't reach their design lifetime (20 years) $[65,70,71]$. The failure of these critical components directly affects the wind turbine and the wind farm performance. Other studies $[65,72,73]$ also show that wind turbine gearboxes could fail in drastically different ways. The study [72] summarized in Figure 7 covered 289 gearbox failure incidents with 257 confirmable damage records. Figure 7 presents a report of this failure distribution of the gearbox components, where it shows that $70 \%$ of the failures occur in the bearings.

Lantz [71] noticed that the average failure rate during 10 operational years can be estimated at $5 \%$, peaked in years 4,5 and 8 . Also, Lantz [71] remarked that serial failures were observed to have a noteworthy effect on the components. Figure 8 confirms this hypothesis, where it seems that at least two failure modes occur and cause gearbox damage (bimodal distribution) that take turns in 6th-7th year. Besides, since wear is predominant in gearboxes, its failure rate is expected to increase after the 10th year if no good maintenance policy is adopted, further research will be needed in this part to prove the application of the double distribution to gearbox failure rate. Besides, gearbox replacement costs are very high, a cost of 445,000 to $628,000 €$ is needed for the replacement of a 2-3 MW wind turbine gearbox $[66,68,74]$. An average expected failure cost of this critical sub-system is around $493,000 €$ (see Table A2), it also causes the highest loss of production cost $(16,000 €)$. 

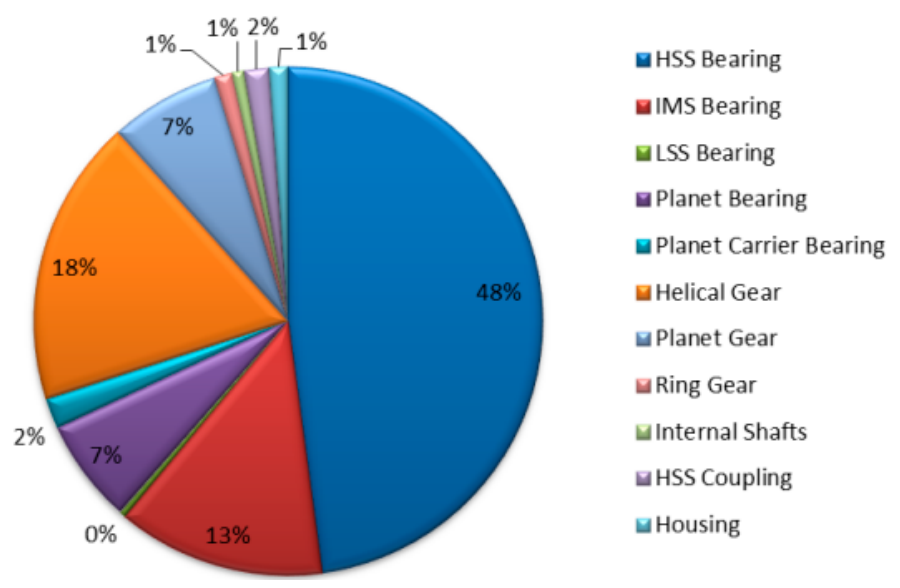

Figure 7. Failure distribution of gearbox components [72].

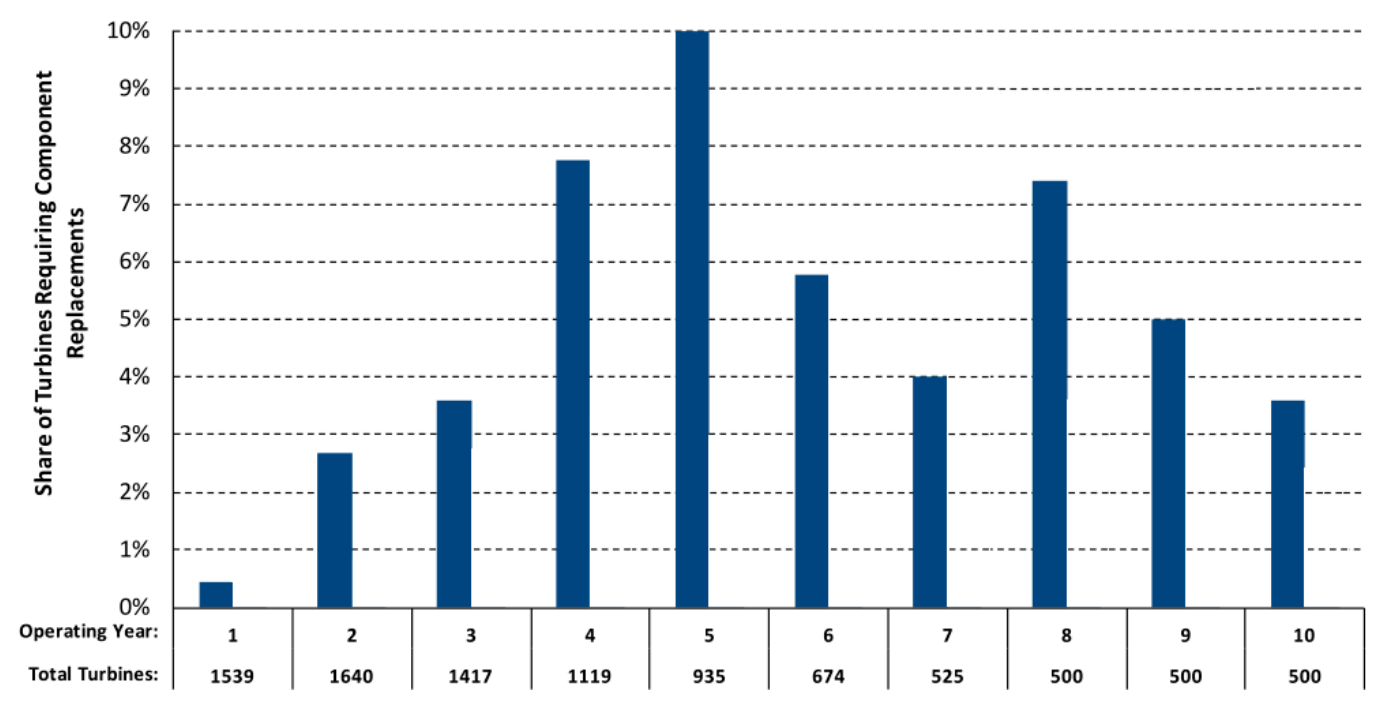

Figure 8. Average annual replacement rate of gearboxes [71].

Figure 8 states about average annual replacement rate of gearboxes, this replacement is not only caused by wear, since several failures can lead to component replacement. To prevent these failures, several solutions are proposed to improve the maintenance process such as condition monitoring solutions.

\subsection{Rotor-Blades Sub-System-A Reliability Overview}

According to Figure 4 and failure rate data extracted from different wind farms [52-55,62], rotor-blade sub-system causes high downtimes if failures occur. Figure 9 describes the proportion of this sub-system downtime regarding its failure rate.

Hill et al. in [75] and this FMEA analysis point out the most frequent reported damages in rotor-blades, they can be:

- Manufacturing issues (waving and overlaid laminates)

- Bad bonds

- Delamination

- Voids

- Leading edge erosion/trailing edge splits

- $\quad$ Scorching and split (due to lightning) 


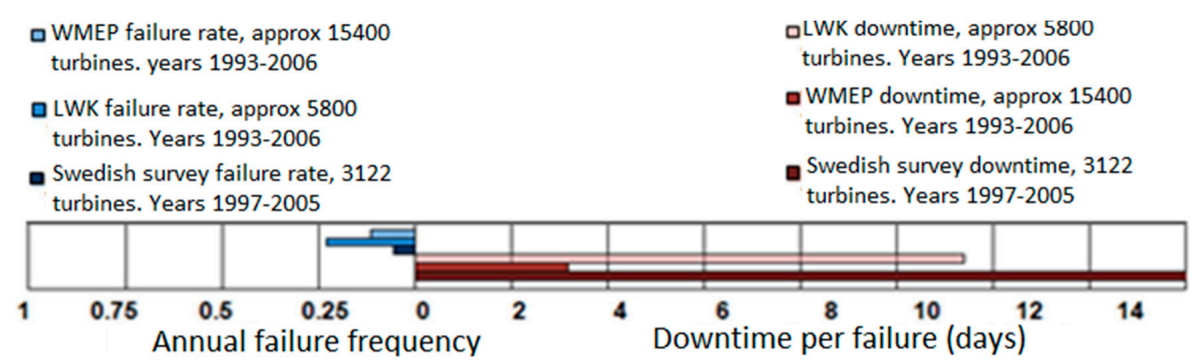

Figure 9. Annual failure frequency and downtime per failure for rotor-blades sub-system [53].

This last cause of failure (lightning strikes) is the most common noted cause of failure in [71]. Besides, in winter or when the temperature gets down $2{ }^{\circ} \mathrm{C}$, icing appears and can cause rotor imbalance. Ice falling from blades can even cause human or animal accidents. Lantz presented in [71] the average blade replacements during 10 operational years over more than 1000 wind turbines. Figure 10a represents this study, where we notice a $1 \%$ to $3 \%$ of the surveilled wind turbines require blade replacement, with spikes in the 1st and 5th year.

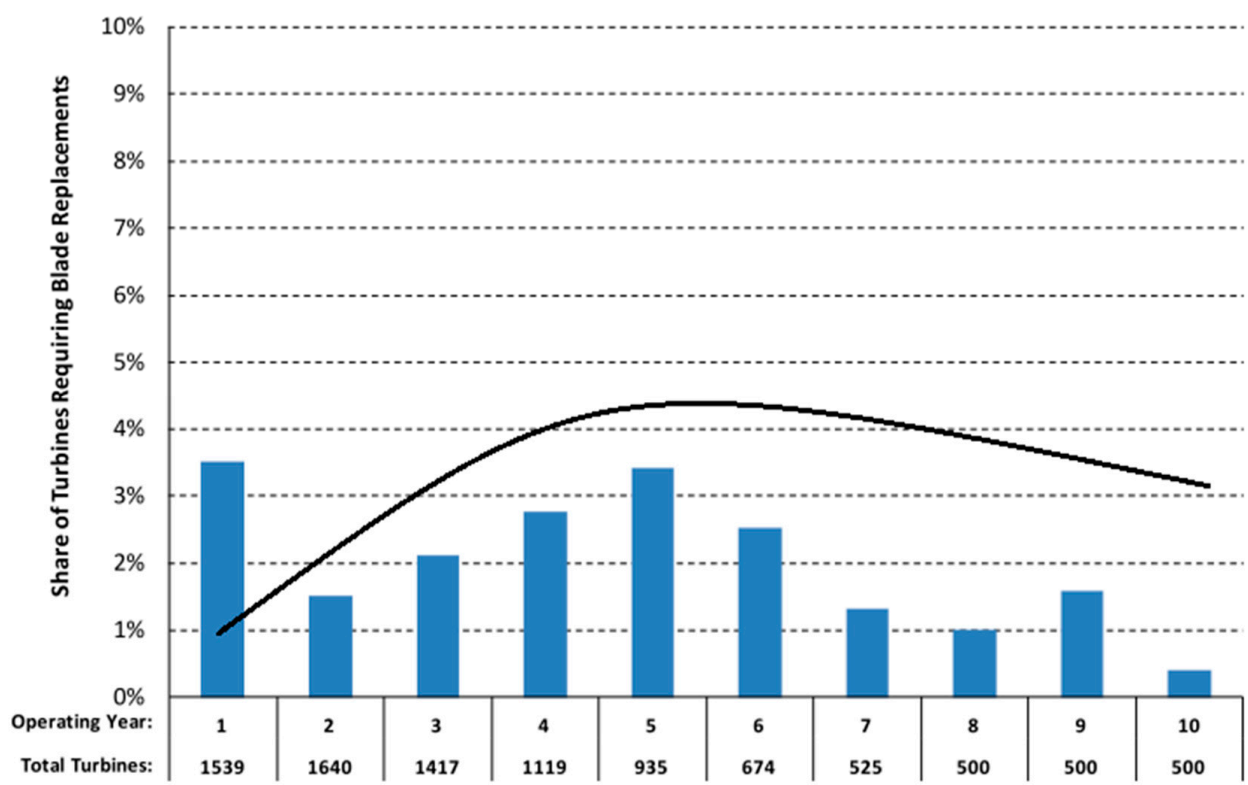

(a)

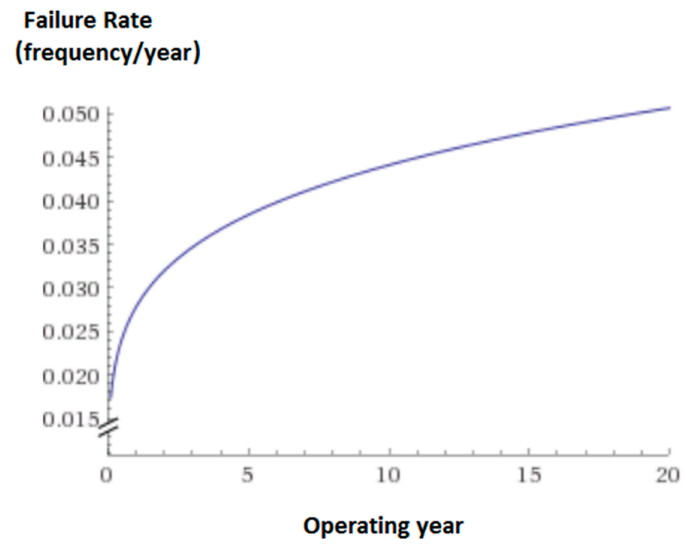

(b)

Figure 10. (a) Average annual probabilities for blade replacements dependent on the operational-the black curve is a fitted Weibull curve; (b) failure rate of blades over 20 years. 
Lantz in [71] points out that blade replacements in the 1st and 2nd years are typically the result of manufacturing defects or damage occurring during the construction process. Besides, he calculates about $2 \%$ of wind turbines blade replacements per year (over 10 operational years). From the other side, we could say from the figure that a similar curve can be found if we describe a Weibull behavior of blade failures, the inconsistency between failure rate curve and replacement rates between the 7th and the 10th year is mainly due to the maintenance policy adopted. Wind extreme load, bad maintenance and delamination leading to fatigue are expected to increase blade failure rates (even after the 10th year) Figure $10 \mathrm{~b}$ presents the evolution of the blade failure rate during 20 years, under Weibull function with a shape parameter of $\beta=1.2$ and a scale parameter of $\eta=23.02$. Further research will be needed in this part to prove the application of this distribution to this sub-system during his lifetime. Figure 10a states the average annual replacement rate of blades, and this replacement is not only caused by fatigue, since several failures can lead to component replacement.

\subsection{Failure Detection}

Visual inspection remains one of the most present failure detection techniques in wind turbine systems. It remains necessary for making decisions on maintenance or safety related to wind turbine shutdown [76]. FMEA analysis shows that failure detection can vary from simple visual detection to complex tools and methods. It can be thus more efficient in wind turbine systems in order to reach high reliability and minimize failures.

The literature shows that $99 \%$ of equipment failures are preceded by certain signs, conditions, or incitation that a failure is going to occur [77]. Nowadays, one of the most used techniques in wind farms are condition monitoring systems (CMSs) [78-81]. This technique rely on sensors or other components that monitor the mechanical, heat or pressure behavior of the observed component. Nowadays, the most predominant CMSs for wind turbines are "vibration-based systems monitoring the rotating drivetrain components". CMS is generally applied to the main bearing, gearbox, generator bearings and tower oscillations. This choice is justified by the recommendation of main insurance companies since 2003 for onshore and offshore wind turbines [82]. Insurance companies does not require CMS for other wind turbine component (electrical and control system for instance), but wind turbine constructors do provide such solutions to monitor wind turbine sub-systems since guidelines and standards for wind turbines CMS were developed (ISO 13373-1 [83], IEC 61400-25-6 [84]).

Besides, Rolfes et al. describe in [76] that rotor-blade monitoring systems available on the market must be considered as being in a development stage, since high downtimes are always registered for this sub-system.

\subsection{Failure Effects}

Considering this FMEA analysis, failure effects exist in wind turbine sub-systems and may lead to failure propagation. The main components mounted in series inside the nacelle (main shaft, gearbox, generator) are highly influenced by their external environments. A vibration generated in the main shaft for instance can lead to a failure in gearbox bearings. This can conclude to the identification of dependencies between wind turbine components. This part was not developed in this paper and will be the object of our next research work.

\section{Conclusions}

In this study, we deal firstly with a system analysis to fix the main configuration of a generic 2-3 MW industrial wind turbine. The application of the hybrid cost-FMEA approach has been discussed and demonstrated for wind turbine system, this method used less data and proved to be as accurate as compared methods. The criticality assessment in the existent approaches was based on failure and occurrence probabilities and cost consequences of failures, whereas the proposed approach is based on failure rates, expected costs of failure and loss of production costs. No failure rates or occurrence probabilities were needed in this method. The reliability analysis proved that: 
- Wear is the main and most common cause of failure in wind turbine systems. The system environment is the main reason for this issue. Wear can cause a variety of operational problems including misalignment and system vibrations. Abrasive and corrosive wear seem to be the most frequent wear type noticed, whereas fatigue influences more external components such as blades.

- Control and electric sub-systems have the highest failure rates in a wind energy system on the one hand. On the other hand, sub-systems such as gearboxes and rotor-blades have low failure rates, but cause high downtimes to the system.

- Expected failure costs were calculated for main wind turbine sub-systems. The study proved that gearboxes and rotor-blades are the critical sub-systems. A general overview of these sub-systems' reliability was presented

- Failure detection techniques were presented. CMS is accurate to prevent failures and minimize downtimes in wind turbine system.

Although the wind industry tries to handle the failure intensities of the different sub-systems, it is recommended that critical sub-systems such as gearboxes and blades should be tested more studiously than nowadays in order to avoid early failures. A suggestion is that wind turbine gearbox failures behaviors could be benchmarked with other gearbox failures in the industry.

This study was compared to others performed for wind turbine systems. The wind industry is in rapid growth and the wind technology is constantly improving. Updated FMEA analysis should be made not only to compare new wind turbine versions to old ones, but also to update reliability information about these systems. The reliability analysis presented in this paper is more concentrated on the design phases, no maintenance policy was introduced here. Thus, this study does not assess the wind turbine reliability through time.

The FMEA analysis also points out the influence of each component on the sub-system itself and its influence on the wind turbine. This will allow us in future research to determine the dependencies between wind turbine components. Such dependencies can affect the reliability analysis and the performance of the system. Future research will also focus on implementing maintenance in this FMEA model.

Acknowledgments: This work is supported by the French regional council of Champagne-Ardenne and the European regional development fund (Fonds européen de développement économique regional-FEDER). Regards also to all contributors in wind turbine FMECA project.

Author Contributions: Authors conceived and developed the methods then analyzed the results. Nacef Tazi wrote the paper and all authors contributed with text and comments.

Conflicts of Interest: The authors declare no conflict of interest. 


\section{Appendix A}

Table A1. Sample of a 2 MW FMEA analysis.

\begin{tabular}{|c|c|c|c|c|c|c|c|c|}
\hline Sub-System & Component & Failure Mode & Failure Causes & Failure Consequences & $\begin{array}{l}\text { LWK Failure } \\
\text { DATA }\end{array}$ & $\begin{array}{l}\text { Failure Rate } \\
134 \text { Wind Turbines } \\
1.5 \mathrm{MW}\end{array}$ & $\begin{array}{c}\text { ISET Germany } \\
\text { Failure DATA, } \\
1500 \text { WT aver } \\
15 \text { Years [9] }\end{array}$ & $\begin{array}{l}\text { LWK Failure DATA, } \\
5800 \text { WT over } 2 \text { Years }\end{array}$ \\
\hline \multirow{4}{*}{ Gearbox } & Toothed shaft & $\begin{array}{l}\text { Fatigue \& } \\
\text { fracture }\end{array}$ & $\begin{array}{l}\text { Irregular grooving/welding } \\
\text { defect/non alignment }\end{array}$ & Shaft cracks/non alignment & \multirow{4}{*}{$4 \%$} & \multirow{4}{*}{$3.26 \%$} & \multirow{4}{*}{$4 \%$} & \multirow{4}{*}{$8 \%$} \\
\hline & Lubricant system & Loss of function & $\begin{array}{l}\text { Presence of water or debris in } \\
\text { the system/aged oil/ } \\
\text { pump failure }\end{array}$ & Overheating/wear & & & & \\
\hline & Gears/gearing & $\begin{array}{l}\text { accelerated } \\
\text { wear/premature } \\
\text { failure }\end{array}$ & $\begin{array}{c}\text { Poor lubrication/presence of } \\
\text { corrosive elements/presence } \\
\text { of water in the lubricant } \\
\text { oil/shocks }\end{array}$ & Damages in the system & & & & \\
\hline & Pipes & Leakage & $\begin{array}{l}\text { Wear/excessive pressure } \\
\text { in pipes }\end{array}$ & $\begin{array}{c}\text { Loss of } \\
\text { precision/Overheating }\end{array}$ & & & & \\
\hline \multirow{2}{*}{ Blade -rotor } & Blades & Fouling & $\begin{array}{l}\text { Climate/snow/hail/dust/ } \\
\text { insects/environmental debris }\end{array}$ & $\begin{array}{l}\text { Loss of aerodynamic } \\
\text { properties/blades are not } \\
\text { optimal for wind } \\
\text { energy saving } \\
\end{array}$ & $7 \%$ & $1 \%$ & $7 \%$ & $10 \%$ \\
\hline & Hub & Fatigue/crack & $\begin{array}{l}\text { Overload/delamination/ } \\
\text { extreme wind } \\
\text { conditions/lightening }\end{array}$ & Crack evolution/rotor stop & $5 \%$ & $3.25 \%$ & $5 \%$ & $5 \%$ \\
\hline $\begin{array}{c}\text { Swedish Power } \\
\text { Plants Failure } \\
\text { DATA, over } 4 \text { Years }\end{array}$ & $\begin{array}{l}\text { WMEP FAILURE } \\
\text { DATA, } 1435 \text { WT } \\
\text { Over } 2 \text { Years }\end{array}$ & $\begin{array}{c}\text { Windstats } \\
\text { Denmark } \\
\text { Failure DATA }\end{array}$ & $\begin{array}{l}\text { Windstats Germany } \\
\text { Failure DATA }\end{array}$ & $\begin{array}{c}\text { EPRI California } \\
\text { Failure DATA, } 290 \text { WT } \\
\text { Over } 2 \text { Years }\end{array}$ & $\begin{array}{c}\text { Reliawind } \\
\text { RELEX } \\
\text { Failure DATA }\end{array}$ & $\begin{array}{l}\text { Failure Effects on } \\
\text { the Sub-System }\end{array}$ & $\begin{array}{l}\text { Failure Effects } \\
\text { on the System }\end{array}$ & Failure Detection Methods \\
\hline $10 \%$ & $5 \%$ & $7 \%$ & $3 \%$ & $3 \%$ & $5 \%$ & $\begin{array}{c}\text { Main shaft } \\
\text { vibration/Generator } \\
\text { vibration } \\
\text { Noise/Gearbox life } \\
\text { time reduction } \\
\end{array}$ & $\begin{array}{l}\text { Emergency stop } \\
\text { activation }\end{array}$ & $\begin{array}{l}\text { Vibration sensors/Oil \& } \\
\text { heat sensors }\end{array}$ \\
\hline $13 \%$ & $12 \%$ & $8 \%$ & $6 \%$ & $7 \%$ & $1 \%$ & $\begin{array}{l}\text { Vibration/crack } \\
\text { evolution/crack } \\
\text { evolution on rotor }\end{array}$ & $\begin{array}{l}\text { Emergency stop } \\
\text { activation }\end{array}$ & $\begin{array}{c}\text { Blade sensors/vibration } \\
\text { sensors in hub/emergency } \\
\text { stop activation/visual } \\
\text { inspection in } \\
\text { maintenance operations }\end{array}$ \\
\hline- & $2 \%$ & - & $3.20 \%$ & $3.40 \%$ & $1.9 \%$ & & & $\begin{array}{l}\text { Visual inspection/ } \\
\text { rotor Sensors }\end{array}$ \\
\hline
\end{tabular}


Table A2. Data used to calculate the expected failure costs generated in a 2-3 MW wind turbine system.

\begin{tabular}{|c|c|c|c|c|c|c|c|c|c|}
\hline \multirow[t]{2}{*}{ Sub-System } & \multirow{2}{*}{$\begin{array}{l}\text { Failure Rate } \\
\text { (N/year) }[21,63]\end{array}$} & \multirow{2}{*}{$\begin{array}{c}\text { Annual } \\
\text { Reliability }\end{array}$} & \multirow{2}{*}{$\begin{array}{l}\text { Average Replacement } \\
\text { Cost (€) (Including } \\
\text { Crane + Labor) [66-68] }\end{array}$} & \multirow{2}{*}{$\begin{array}{c}\text { Average } \\
\text { Downtime } \\
\text { per Hours }[63,64]\end{array}$} & \multicolumn{3}{|c|}{$\begin{array}{l}\text { Average Cost of Loss of Production; } \\
\text { Selling Tariff } 0.082(€ / \mathrm{kWh})\end{array}$} & \multirow{2}{*}{$\begin{array}{l}\text { Expected } \\
\text { Cost of } \\
\text { Failure }(€)\end{array}$} & \multirow{2}{*}{$\begin{array}{l}\text { Criticality } \\
(€ / \mathbf{k W h})\end{array}$} \\
\hline & & & & & $2 \mathrm{MW}$ & $3 \mathrm{MW}$ & Average & & \\
\hline Structure & 0.09 & 0.913 & $682,386.00$ & 97.00 & 4772.40 & 7158.60 & 5965.50 & $628,983.92$ & $56,608.55$ \\
\hline Rotor-blades & 0.17 & 0.843 & $305,873.33$ & 146.53 & 7209.44 & $10,814.16$ & 9011.80 & $266,863.02$ & $45,366.71$ \\
\hline Main shaft & 0.05 & 0.951 & $199,170.00$ & 181.77 & 8942.92 & $13,414.38$ & $11,178.65$ & $200,589.32$ & $10,029.47$ \\
\hline Generator & 0.1 & 0.904 & $189,908.00$ & 126.13 & 6205.76 & 9308.64 & 7757.20 & $179,434.03$ & $17,943.40$ \\
\hline Yaw system & 0.18 & 0.835 & $199,990.00$ & 67.93 & 3342.32 & 5013.48 & 4177.90 & $171,169.55$ & $30,810.52$ \\
\hline Converter & 0.24 & 0.786 & $81,272.00$ & 90.00 & 4428.00 & 6642.00 & 5535.00 & $69,414.79$ & $16,659.55$ \\
\hline Electrical system & 0.55 & 0.576 & $33,980.00$ & 72.93 & 3588.32 & 5382.48 & 4485.40 & $24,057.88$ & $13,231.83$ \\
\hline Control system & 0.41 & 0.663 & $28,388.00$ & 55.20 & 2715.84 & 4073.76 & 3394.80 & $22,216.04$ & 9108.58 \\
\hline Hydraulic system & 0.23 & 0.794 & $23,300.00$ & 41.47 & 2040.16 & 3060.24 & 2550.20 & $21,050.40$ & 4841.59 \\
\hline Mechanical Brake & 0.13 & 0.878 & 8560.00 & 65.60 & 3227.52 & 4841.28 & 4034.40 & $11,550.08$ & 1504.51 \\
\hline Others & 0.11 & 0.895 & 5000.00 & 105.60 & 5195.52 & 7793.28 & 6494.40 & $10,969.40$ & 1206.63 \\
\hline
\end{tabular}




\section{References}

1. Global Wind Energy Council (GWEC). Global Wind Energy Council, June 2016. Available online: http: / / www.gwec.net/ (accessed on 7 June 2016).

2. France Energie Eolienne (French wind energy)_FEE. Classement des Constructeurs par MW Installés en France (Manufacturer Ranking per MW in France). Available online: http:/ / fee.asso.fr/centre-infos / ressources-multimedia/en-france (accessed on 1 September 2016).

3. GWEC. GWEC Global Wind Report, 2015. Available online: http://www.gwec.net/publications/globalwind-report-2/global-wind-report-2015-annual-market-update/) (accessed on 7 June 2016).

4. International Electrotechnical Commission (IEC). Chapter 191: Dependability and Quality of Service; International Electrotechnical Vocabulary, IEC 60050-191:1990; International Electro technical Commission: Geneva, Switzerland, 1990.

5. American Society for Quality (ASQ). Glossary: Reliability. Available online: http://asq.org/glossary/r.html (accessed on 15 January 2017).

6. Department of Defense Handbook. MIL-HDBK-189C. Reliability Growth Management. 2011. Available online: http://www.weibull.com/mil_std/mil_hdbk_189c.pdf (accessed on 7 July 2016).

7. Bi, R.; Qian, K.; Zhou, C.; Hepburn, D.; Rong, J. A survey of failures in wind turbine generator systems with focus on a wind farm in China. Int. J. Smart Grid Clean Energy 2014, 366-373. [CrossRef]

8. Ole, H.; Nicola, B.N. Reliability of State-of-the-Art Wind Farms; UpWind: Fredericia, Denmark, 2007.

9. Hahn, B.; Durstewitz, M.; Rohrig, K. Reliability of Wind Turbines. January 2006. Available online: https://www.researchgate.net/publication/46383070_Reliability_of_wind_turbines_Experiences_of_15_ years_with_1500_WTs (accessed on 14 June 2016).

10. Mentes, A.; Ozen, E. A hybrid risk analysis method for a yacht fuel system safety. Saf. Sci. 2015, 79, 94-104. [CrossRef]

11. Marhavilas, P.; Koulouriotis, D.; Gemeni, V. Risk analysis and assessment methodologies in the work sites: On a review, classification and comparative study of the scientific literature of the period 2000-2009. J. Loss Prev. Process Ind. 2011, 24, 477-523. [CrossRef]

12. Talon, A.; Boissier, D.; Peyras, L. Présentation Détaillée des Méthodes D'analyse de Risques (Detailed Presentation of Risk Analysis Methodologies). Available online: http:/ /www.unit.eu/cours/cyberrisques / etage_3_aurelie/co/Module_Etage_3_synthese_26.html (accessed on 1 September 2016). (In French)

13. NEM Business Solutions. Risk Analysis Methodologies. Available online: http://nem.org.uk/risk.htm\# Risk\%20Analysis (accessed on 1 September 2016).

14. Health and Safety Laboratory. Review of Hazard Identification Techniques; Health and Safety Laboratory, HSL/2005/58; Health and Safety Laboratory (HSL): Sheffield, UK, 2005.

15. Rhee, S.J.; Ishii, K. Life cost based FMEA incorporating data uncertainty. In Proceedings of the ASME 2002 International Design Engineering Technical Conferences and Computers and Information in Engineering Conference, Montreal, QC, Canada, 29 September-2 October 2002.

16. Rhee, S.J.; Ishii, K. Using cost based FMEA to enhance reliability and serviceability. Adv. Eng. Inf. 2003, 17, 179-188. [CrossRef]

17. Hyatt, N. Guidelines for Process Hazards Analysis, Hazards Identification \& Risk Analysis; Dyadem Press: Richmond Hill, ON, USA, 2004.

18. Mentes, A.; Helvacioglu, I. Review of fuzzy set theory applications in safety assessment for marine and offshore industries. In Proceedings of the ASME 2011 30th International Conference on Ocean, Offshore and Arctic Engineering OMAE, Rotterdam, The Netherlands, 19-24 June 2011.

19. American Bureau for Shipping (ABS). Guidance Notes on Risk Assessment Applications for the Marine and Offshore Oil and Gas Industries; American Bureau for Shipping (ABS): Houston, TX, USA, 2000.

20. Chien, L.-K.; Chiu, S.-Y.; Tseng, W.-C.; Chen, K.-H. Risk Assessment of Offshore Wind-Farm Construction. In Proceedings of the Twenty-Third (2013) International Offshore and Polar Engineering (ISOPE), Anchorage, AK, USA, 30 June-4 July 2013.

21. Botsaris, P.; Konstantinidis, E.; Pitsa, D. Systemic assessment and analysis of factors affect the reliability of a wind turbine. Institut za Istraživanja i Projektovanja u Privredi IIPP 2012, 10, 85-92.

22. Seebregts, A.; Rademakers, L.; van den Horn, B. Reliability analysis in wind turbine engineering. Microelectron. Reliab. 1995, 35, 1285-1307. [CrossRef] 
23. Shafiee, M.; Dinmohammadi, F. An FMEA-based risk assessment approach for wind turbine systems: A comparative study of onshore and offshore. Energies 2014, 7, 619-642. [CrossRef]

24. Kahrobaee, S.; Asgarpoor, S. Risk-based Failure Mode and Effect Analysis for wind turbines (RB-FMEA). In Proceedings of the North American Power Symposium (NAPS 2011), Boston, MA, USA, 4-6 August 2011; Northeastern University: Boston, MA, USA, 2011.

25. Luko, S.N. Reviews of standards and related material risk assessment techniques. Qual. Eng. 2014, 26, 379-392. [CrossRef]

26. Yang, X.; Li, J.; Liu, W.; Guo, P. Petri net model and reliability evaluation for wind turbine hydraulic variable pitch systems. Energies 2011, 4, 978-997. [CrossRef]

27. Leigh, J.; Dunnett, S. Use of Petri nets to model the maintenance of wind turbines. Qual. Reliab. Eng. Int. 2016, 32, 167-180. [CrossRef]

28. Health and Safety Laboratory (HSL). Machinery Risk Assessment Validation, Literature Review; Health and Safety Laboratory, HSL/2000/18; HSL: Sheffield, UK, 2000.

29. Tague, N.R. The Quality Toolbox, 2nd ed.; ASQ Quality Press: Milwaukee, WI, USA, 2004; pp. $236-260$.

30. Betancourt, L.; Birla, S.; Gassino, J.; Regnier, P. Suitability of Fault Modes and Effects Analysis for Regulatory Assurance of Complex Logic in Digital Instrumentation and Control Systems; NUREG/IA-0254 U.S. Nuclear Regulatory Commission-International Agreement Report; WDC: Washington, DC, USA, 2011.

31. Villacourt, M. Failure Mode and Effects Analysis (FMEA): A Guide for Continuous Improvement for the Semiconductor Equipment Industry; SEMATECH: Austin, TX, USA, 1992.

32. Chrysler, L.L.C. Potential Failure Mode and Effects Analysis (FMEA); Automotive Industry Action Group (AIAG): Southfield, MI, USA, 2008.

33. Association Française de Normalisation (AFNOR). CEI 60812:2006-Techniques D'analyse de la Fiabilité du Système-Procédure D'analyse des Modes de Défaillance et de Leurs Effets (AMDE) (Reliability Analysis Techniques: Failure Mode and Effect Analysis Procedure FMEA); Commission Electrotechnique Internationale (CEI): Geneva, Switzerland, 2006. (In French)

34. Egerton, C. Choosing between Failure Modes and Effects Analysis (FMEA) and Fault Tree Analysis (FTA). Available online: http://egertonconsulting.com/choosing-between-failure-modes-and-effects-analysisfmea-and-fault-tree-analysis-fta / (accessed on 1 September 2016).

35. Suiran, Y.; Jiwen, L.; Qingyan, Y.; Minxian, P. A comparison of FMEA, AFMEA and FTA. In Proceedings of the 9th International Conference on Reliability, Maintainability and Safety (ICRMS), Guiyang, China, 12-15 June 2011.

36. Sheng, S.; Veers, P. Wind Turbine Drivetrain Condition Monitoring-An Overview. National Renewable Energy Laboratory (NREL). 2011. Available online: https://pdfs.semanticscholar.org/ce7b/ 28efbe63035f5871fa3b383c23941362d4a8.pdf (accessed on 7 September 2016).

37. Arabian-Hoseynabadi, H.; Oraee, H.; Tavner, P. Failure modes and effects analysis (FMEA) for wind turbines. Int. J. Electr. Power Energy Syst. 2010, 32, 817-824. [CrossRef]

38. Tavner, P.; Higgins, A.; Arabian, H.; Long, H.; Feng, Y. Using an FMEA method to compare prospective wind turbine design reliabilities. In Proceedings of the European Wind Energy Conference, EWEC 2010, Warsaw, Poland, 20-23 April 2010.

39. Bharatbhai, M.G. Failure mode and effect analysis of repower $5 \mathrm{MW}$ wind turbine. Int. J. Adv. Res. Eng. Sci. Technol. 2015, 2, 2393-9877.

40. Sinha, Y.; Steel, J.A. A progressive study into offshore wind farm maintenance optimization using risk based failure analysis. Renew. Sustain. Energy Rev. 2015, 42, 735-742. [CrossRef]

41. Dinmohammadi, F.; Shafiee, M. A fuzzy FMEA risk assessment approach for offshore wind turbines. Int. J. Progn. Health Manag. 2013, 4, 1-8.

42. Das, M.; Panja, S.; Chowdhury, S.; Elombo, A. Expert-based FMEA of wind turbine system. In Proceedings of the 2011 IEEE International Conference on Industrial Engineering and Engineering Management (IEEM), Singapore, 6-9 December 2011.

43. Zhou, A.; Yu, D.; Zhang, W. A research on intelligent fault diagnosis of wind turbines based on ontology and FMECA. Adv. Eng. Inf. 2015, 29, 115-125. [CrossRef]

44. Fischer, K.; Besnard, F.; Bertling, L. Reliability centred maintenance for wind turbines based on statistical analysis and practical experience. IEEE Trans. Energy Convers. 2012, 27, 1-12. [CrossRef] 
45. Andrawus, J.A.; Watson, J.; Kishk, M.; Adam, A. The Selection of a suitable maintenance strategy for wind turbines. Wind Eng. 2006, 30, 471-486. [CrossRef]

46. Wilkinson, M.; Spinato, F.; Knowles, M. Towards the zero maintenance wind turbine. In Proceedings of the 41st International Universities Power Engineering Conference, Newcastle, UK, 6-8 September 2006.

47. Garcia, M.E.I.; Sanchez, A.; Barbati, S. Reliability and Preventive Maintenance. In New Materials and Reliability in Offshore Wind Turbine Technology; Springer: Rome, Italy, 2016; pp. 235-272.

48. Rui, J.; Kaili, Z.; Zhiyong, M.; Dameng, W. Fault mode, effects and criticality analysis for overheating fault of wind turbines gearbox and generator. In Proceedings of the International Conference on Renewable Power Generation (RPG 2015), Beijing, China, 17-18 October 2015.

49. Kang, J.; Sun, L.; Sun, H.; Wu, C. Risk assessment of floating offshore wind turbine based on correlation-FMEA. Ocean Eng. 2017, 129, 382-388. [CrossRef]

50. Alinezhad, R.; Afzalian, A.A. Failure mode and effect analysis and fault modelling of wind turbine for FTC approach. In Proceedings of the Conference on Thermal Power Plants (CTPP), Tehran, Iran, 18-19 December 2012.

51. Peng, Y.; Asgapoor, S.; Qiao, W.; Foruzan, E. Fuzzy cost-based FMECA for wind turbines considering condition monitoring systems. In Proceedings of the North American Power Symposium (NAPS), Denver, CO, USA, 18-20 September 2016.

52. Van Bussel, G.; Zaaijer, M. Estimation of Turbine Reliability Figures within the DOWEC Project; DOWEC Report; Energy Research Centre of the Netherlands (ECN): Petten, The Netherlands, 2003; Available online: https://www.ecn.nl/fileadmin/ecn/units/wind/docs/dowec/10048_004.pdf (accessed on 7 October 2016).

53. Faulstich, S.; Lyding, P.; Hahn, B. Electrical subassemblies of wind turbines, a substantial risk for the availability. In Proceedings of the European Wind Energy Conference and Exhibition (EWEC), Warsaw, Poland, 20-23 April 2010.

54. Vindkraft, D. Driftuppföljning Vindkraft (Wind Turbine Operation). June 2016. Available online: http:/ / vindstat.com/rapporter-2/ (accessed on 7 June 2016).

55. Stenberg, A. Analys av Vindkraftsstatistik i Finland (Wind Turbine Analysis in Finland). Master's Thesis, VTT, Stockholm, Sweden, 2010. Available online: http:/ / www.vtt.fi/files/projects/windenergystatistics / diplomarbete.pdf (accessed on 6 June 2016).

56. Herman, K.; Walker, R.; Winikson, M. Availability Trends Observed at Operational Wind Farms. In Proceedings of the European Wind Energy Conference \& Exhibition (EWEC) 2008, Brussels, Belgium, 31 March-3 April 2008.

57. Wolfram. Standard Deviation. Available online: http://mathworld.wolfram.com/StandardDeviation.html (accessed on 12 January 2017).

58. International Energy Agency (IEA). Wind Energy—Technology Roadmap; IEA: Geneva, Switzerland, 2013.

59. American Wind Energy Association (AWEA). Turbines Manufacturers \& Rankings-AWEA. Available online: http:/ / www.awea.org/AnnualMarketReport.aspx?ItemNumber=6313 (accessed on 1 September 2016).

60. WindPower. Ten of the Biggest and the Best Manufacturers. Available online: http://www. windpowermonthly.com/article/1352888/ten-biggest-best-manufacturers (accessed on 1 September 2016).

61. Li, H.; Chen, Z. Overview of different wind generator systems and their comparisons. IET Renew. Power Gener. 2008, 2, 123-138. [CrossRef]

62. Uchida, Y.; Walker, R.; Winikson, M. Availability Trends Observed at Operational Wind Farms. Proc. Jpn. Wind Energy Symp. 2008, 30, 144-147.

63. Ribrant, J. Reliability Performance and Maintenance, a Survey of Failures in Wind Power Systems. Master's Thesis, KTH School of Electrical Engineering, Stockholm, Sweden, 2006.

64. Faulstich, S.; Lyding, P.; Hahn, B. Component Reliability Ranking with Respect to WT Concept and External Environmental Conditions; UPWIND Deliverable WP7.3; Energy Research Center of The Netherlands: Petten, The Netherlands, 2010.

65. Sheng, S. Report on Wind Turbine Subsystem Reliability - A Survey of Various Databases; National Renewable Energy Laboratory (NREL): Golden, CO, USA, 2013.

66. Tretton, M.; Reha, M.; Drunsic, M. Data Collection from Current U.S Wind Energy Projects: Component Costs, Financing, Operations, and Maintenance; Subcontract Number NREL/SR-5000-5270; National Renewable Energy Laboratory (NREL): Golden, CO, USA, 2011. 
67. International Renewable Energy Agency (IRENA). Renewable Energy Technologies: Cost Analysis Series; IRENA: Abu Dhabi, UAE, 2012.

68. Moné, C.; Smith, A.; Maples, B.; Hand, M. 2013 Cost of Wind Energy Review; Technical Report: NREL/TP-5000-63267; National Renewable Energy Laboratory (NREL): Golden, CO, USA, 2015.

69. Rahimi, M. Dynamic performance assessment of DFIG-based wind turbines: A review. Renew. Sustain. Energy Rev. 2014, 37, 852-866. [CrossRef]

70. Liu, J. Research on Fault Diagnosis System of Gearbox in Large Wind Turbines. Master's Thesis, University of Technology of Guangdong, Guangzhou, China, 2013.

71. Lantz, E. Operations Expenditures: Historical Trends and Continuing Challenges. In Proceedings of the AWEA Wind Power Conference, Chicago, IL, USA, 5-8 May 2013.

72. Zhao, H.; Hu, Q.; Li, Z. Failure prediction of wind turbine gearbox based on statistical process control. Power Syst. Prot. Control 2012, 40, 67-73.

73. Zhou, Y.; Liu, Y.; Zhao, Q.; Li, H. Fault feature extraction from wind turbine gearbox based on non-Gaussian intensity. J. Chin. Soc. Power Eng. 2013, 33, 865-870.

74. Yang, W.; Sheng, S.; Court, R. Operational condition independent criteria dedicated to monitoring wind turbine generators. In Proceedings of the ASME 2012 International Mechanical Engineering Congress \& Exposition, Houston, TX, USA, 9-15 November 2012.

75. Hill, R.; Peters, V.; Stinebaugh, J.; Veers, P. Wind Turbine Reliability Database Update; Sandia National Laboratories: Livermore, CA, USA, 2009.

76. Rolfes, R.; Tsiapoki, S.; hackell, M. Sensing solutions for assessing and monitoring wind turbines. Sensor Technol. Civil Infrastruct. 2014, 19, 565-604.

77. Rosmaini, A.; Shahrul, K. An overview of tie-based and condition based maintenance in industrial application. Comput. Ind. Eng. 2012, 63, 135-149.

78. Vibro, B.K. Condition Monitoring for Wind Turbines. Available online: http://www.bkvibro.com/en/ condition-monitoring/wind-turbines.html (accessed on 1 September 2016).

79. Renewable NRG Systems. Understanding Wind Turbine Condition Monitoring Systems. Available online: https:/ / www.renewablenrgsystems.com/assets/resources/Understanding-Wind-Turbine-ConditionMonitoring-Systems-Whitepaper.pdf (accessed on 1 September 2016).

80. Kluge, M.; Danitschek, M. Condition Monitoring Systems (CMS) in Wind Turbines_IFM Electronics. 22 July 2010. Available online: http://www.ifm.com/obj/ifm_wind_power_CMS_EN.pdf (accessed on 1 September 2016).

81. Tchakoua, P.; Wamkeue, R.; Ouhrouche, M.; Slaoui-Hasnaoui, F.; Tameghe, T.; Ekemb, G. Wind Turbine Condition Monitoring: State-of-the-Art Review, new trends, and future challenges. Energies 2014, 7, 2595-2630.

82. Gellermann, T.; Walter, G. Anforderungen an Condition Monitoring Systeme für Windenergieanlagen (Requirements for Condition Monitoring Systems in Wind Turbines); Allianz Zentrum für Technik: Ismaning, Germany, 2003. (In German)

83. International Organization for Standardization (ISO). Condition Monitoring and Diagnostics of Machines_Vibration Condition Monitoring_Part 1: General Procedures; ISO 13373-1:2002; ISO: Geneva, Switzerland, 2002.

84. International Electrotechnical Commission (IEC). Wind Energy Generation Systems-Part 25-6: Communications for Monitoring and Control of Wind Power Plants_Logical Node and Data Classes for Condition Monitoring; IEC 61400-25-6:2016; IEC: Geneva, Switzerland, 2016.

(C) 2017 by the authors. Licensee MDPI, Basel, Switzerland. This article is an open access article distributed under the terms and conditions of the Creative Commons Attribution (CC BY) license (http:/ / creativecommons.org/licenses/by/4.0/). 